\title{
The Socio-Economic Impact of Corporate Social Responsibility Practices in Sri Lankan Tea Manufacturing Companies (Special Reference to Kandy District)
}

\author{
I D C WIJERATHNA \\ Ministry of Economic Development \\ Wdilan@live.com \\ RIDMI GAJANAYAKE \\ Department of Commerce \& Financial Management, University of Kelaniya \\ Ridmig@gmail.com
}

\begin{abstract}
Corporate Social Responsibility (CSR) is very important topic in the present competitive business environment. The aim of this exploratory study is to capture the current status of Corporate Social Responsibility (CSR) awareness, commitment and practices level of tea manufacturing companies in Sri Lanka and assessing the socioeconomic impact of company CSR on employees and smallholders. The study provides an overview of company CSR practices as well as of employee and smallholder experiences and perceptions of CSR practices of tea manufacturing companies. The research study is based on Kandy district and three perspectives factory owners, employees and smallholders were used in exploring the CSR level and its socioeconomic impact. To achieve the research objectives tea manufacturing company's CSR practices are studied in three domains: CSR to employees, smallholders and environment. The researcher used mixed method comprising both quantitative and qualitative elements. There is a positive relationship between tea manufacturing company CSR level and the socioeconomic condition of employee and the smallholders. When it consider about the overall situation, current CSR practices of tea manufacturing companies have not made a positive impact on socioeconomic development of employees and smallholders. Tea manufacturing companies should consider CSR strategies that are in the interest of all stakeholders and relevant to the business.
\end{abstract}

Key Words: Corporate Social Responsibility, Tea manufacturing companies, Small holders, Employees, Socioeconomic Condition 


\section{Introduction}

Corporate Social Responsibility (CSR) is a notable topic within the present-day competitive global business arena. CSR can be defined as commitment of business to contribute to sustainable economic development - working with employees, their families, the local community and society at large to improve the quality of life, in ways that are both good for business and good for development (Foreign Investment Advisory Service, 2006). According to Carroll CSR is economic, legal, ethical and philanthropic responsibilities imposed to companies (1979, cited in Marjo Elisa Siltaoja, 2006). For a company to be socially responsible corporation its behavior should entail (Placeholder3)all of these components.

"Companies need to answer to two aspects regarding their operations i.e. the quality of their management and the nature of their impact on societies in various areas" (Baker, 2009). Inside as well as outside stakeholders are interested in learning about the activities of a company. Shareholders, customers, employees, suppliers, sub-contractors, and community etc. are usually referred to as stakeholders of a company. They pay attention to what the companies do and what they have actually done. This may be in terms of products or services, impact on the environment, the operations in the market or in local communities, or among employees. The companies engage in CSR activities because they can have some kind of business benefits such as a good reputation, customer loyalty etc. good business policy with an ethical reference has more influence on reputation of the organization (Siltaoja, 2006). According to the European Commission, CSR is defined as the voluntarily contribution of companies for a better society and a cleaner environment (European Commission, 2001 cited in Mummullage, 2010). It addresses complex issues such as "environmental protection, human resources management, health and safety at work, relations with local communities, relations with suppliers and consumers" (Branco, 2007:5).

In any country, the business sector plays an important role. The economic growth of a country can be sustained by the expansion of manufacturing sector. When it considers about the Sri Lankan manufacturing sector tea sector plays a vital role. Tea is second highest foreign exchange source in Sri Lanka. In 2010 Highest foreign exchange has been generated by Textiles and Garments sector, it is about $\$ 3,504.1$ million. It has generated $\$ 1,375.4$ million by tea export. Tea export is the main export item in Sir Lanka in the aspect of net exports (Sri Lanka central 
bank report 2010). In this perspective, we should study how to achieve sustainability of the tea manufacturing companies.

At present, most of Sri Lankan organizations are seeking to conform to CSR practices since stakeholders and other relevant parties often want to know about a firm's social responsibility. As companies are responsible for their actions with regards to both socio-economic and environmental consequences, therefore they should consider socio-economic and environmental impacts to be a part of their responsibility while at the same time generating profit.

\section{Literature Review}

The concept of corporate social responsibility (CSR) has a long and varied history (Carroll, 1999: 268). Corporate social responsibility (CSR) has been debated and practiced in one form or another for more than 4,000 years (Wayne Visser, 2010). "The ancient Vedic and Sutra texts of Hinduism and the Jatakas of Buddhism include ethical admonitions on usury (the charging of excessive interest) and Islam has long advocated Zakat, or a wealth tax"(Wayne Visser, 2010). According to Wayne Visser (2010) the concept of CSR is not a contemporary business concept it is the way of life and CSR concept has been emerged religious backgrounds. Sri Lanka has a long history of corporate philanthropy. Charitable activities are performed by the business communities to support various needs of the society is not a new concept in Sri Lanka (Ariyabandu \& Hulangamuwa, 2002).

The study of "Corporate Social Responsibility Practices of Sri Lankan Private Sector" is An Exploratory Study by Rathnasiri (2003).According to this study CSR is still a novel concept to many organizations, employees and to civil activists in Sri Lanka.The researcher (Rathnasiri, 2003) has found that in Sri Lankan private companies there is little evidence of examples of internal CSR policies like Better working conditions for employees, gender equality, equal opportunities, waste treatment, truth in advertising, preserving immediate environment, and ethical dealings. "The social dimension of business practices has gained much prominence with the emergence of the human rights movement, environmentalism and gender equality issues etc" (Rathnasiri, 2003).

Mummullage (2010) conducted a study with the title of"socio-economic impacts of corporate social responsibility practices in Sri Lankan domestic manufacturing companies" and this 
empirical investigationis based on a case study of Harischandra Mills PLC CSR practices.According to the study of Mummullage (2010) top management has good awareness about CSR and mid level management, lower level employees and society people do not have an adequate awareness on this matter.Both above studies have highlighted that Sri Lankan companies are more concerned about philanthropic CSR activities. The researcher has generalized that private sector CSR practices are not in adequate level to made positive impact on socio economic condition of employees and society.

Sanne van der Wal (2008) conducted his research study for the organization of "Stichting Onderzoek Multinationale Ondernemingen" (SOMO) Centre for Research on Multinational Corporations.According to the findings of SOMO implementation of Corporate Social Responsibility (CSR) has not received as much attention. Social, economic and environmental issues are, however, now emerging as focal points for the tea industry.Further this study mentions that CSR is still rather underdeveloped at the national level. SOMO (2008) highlights that in Sri Lanka the awareness level of stakeholders on key benefits of adoption of CSR strategies is low and there has also been an increase in their developmental activities in the communities; particularly in the area of philanthropy.The study indicates that working conditions for pickers are often poor, with low wages, low job and income security, discrimination along ethnic and gender lines, lack of protective gear and inadequate basic facilities such as housing and sometimes even drinking water and food.

Oldenziel (2006) conducted a study relating to CSR practices in tea plantation with the title of "Sustainabilitea, The Dutch Tea Market and Corporate SocialResponsibility." This research report has been published by the SOMO - Centre for research on Multinational Corporations.Same as the findings of Sanne van der Wal (2008), Joris Oldenziel (2006) also mentions that the condition of labors in tea plantation is very poor.Further he has found that tea plantation workers are still discriminated against because of this historical context. "For example, in Sri Lanka, the vast majority of tea estate workers are "Tea Tamils" who is isolated even within their own community as the indigenous Sri Lanka Tamils consider them to be second class citizens" (Oldenziel, 2006). 


\section{Research Methodology}

The research of Institute of social development (2008) has assessed the CSR practices of tea plantation companies based on case studies of plantation companies. This study is fully relevant to Sri Lankan context and it has not considered about the stakeholder perspective regarding companies CSR practices. The research studies of Joris Oldenziel (2006) and Sanne van der Wal (2008) have focused on CSR practices of main tea producing countries. Sri Lankan tea plantation industry also has been concerned by the researchers. These researches have more concentrated to find critical issues in tea producing countries relating to tea industry which CSR should be addressed.

According to above literature regarding to Sri Lankan tea plantation, researchers haven't considered about the perspective of most important stakeholders. Base on the literature, consideration about the perspective of employees and small holders regarding socio-economic impact of CSR practices of tea manufacturing companies can be identified as the research gap of current research study.

The following research questions will be addressed through the research study.

1. What kind of CSR practices are performed by tea manufacturing companies?

2. Why they have engaged in CSR practices?

3. What are the perceptions of the owners, small holders and the employees regarding CSR activities/practices?

The main objective of the study is to explore the socio-economic impacts of CSR activities in a Sri Lankan tea manufacturing company. The study is based on CSR practices of five tea manufacturing companies operate in Kandy district. In addition to the main objective, the subobjectives are,

1. To determine the level of CSR practices in tea manufacturing companies.

2. To analyze the perceptions of the different stakeholders regarding the company's CSR activities. ( perception of employees, small holders and owners) 
3. To make suggestions to improve CSR practices of tea manufacturing companies.

In the current research study, the researcher has chosen to make use of both quantitative and qualitative elements. The main objectives of this study is to scrutinize the socioeconomic impacts of CSR practices employed by the Sri Lankan tea manufacturing companies base on Kandy district. By using the conceptual framework that is based on the literature, the researcher concern perspectives of main stake holders like factory owners, smallholders and employees about the CSR practices and socioeconomic impacts. The study is primarily concerned with gaining and understanding of people's perception.

This research regards the socio economic impact of CSR practices of tea manufacturing company in Sri Lanka aims at exploring and obtaining an understanding of involvement of tea manufacturing companies in CSR activities and assesses the impact of CSR activities of Tea manufacturing companies on socio economic development of its main stakeholders. According to the literature CSR activities have been defined under various domains. In the current research study it assesses tea manufacturing companies CSR in three aspects. They are,

$>$ CSR towards employees

CSR towards smallholders

CSR regarding environment

$$
\begin{aligned}
& \text { Company CSR practices } \\
& \text { regarding, } \\
& >\text { Employees } \\
& >\text { Smallholders } \\
& >\text { Environment }
\end{aligned}
$$

Socio-economic impact of CSR activities

\section{Figure 01: Conceptual framework}

Source: Author

This diagram seeks to illustrate the CSR practices of tea manufacturing companies on various domains will affect the socio economic development of employees and small holders. Current research study, CSR status of tea manufacturing companies has been captured from three 
Perspectives: Owners, smallholders and employee perspectives. The Researchers expectation is to get these three perspectives are, identify the CSR practices and CSR level of tea manufacturing companies from perspective of owners and get the perspective of smallholders and employees to assess the socio economic impact of CSR practices of companies.

The Conceptual framework presented above will be used to develop the testable hypothesis for the study. The basis of the hypothesis is that the level of CSR practices of Tea manufacturing companies will be reflected the social and economic condition. To test these ideas and thoughts following three hypotheses are developed by making relationships between company CSR level and its impact on Socioeconomic condition.

H1: Company CSR level for employees will impact on socioeconomic condition of employees.

H2: Company CSR level for smallholders will impact on socioeconomic condition of smallholders

H3: Company overall CSR level will impact overall socioeconomic condition.

In the current research study the perspective of three main stakeholders to be concerned according to the conceptual framework of the research. This study is based on 5 tea manufacturing companies, 70 employees and 70 smallholders. Therefore for this study the sample size is 145 respondents.

Data on corporate social responsibility and its impact were collected from primary sources and minimum secondary data ware used for the achievement of research objectives. Three set of questionnaires are used to gather data and qualitative judgments have been made. Other than interview researcher used field observations to gather some important information for the analysis. 


\section{Findings}

\section{Owner's Perspective of CSR Practices}

\section{Vision and Mission Statement}

Almost $80 \%$ of factory owner responded that they have mission and vision statements. In general, most of the firms in the sample do not seem to have mentioned in their mission statements commitment toward key stakeholders such as employees, smallholders and environment. In addition, areas of corporate responsibility are not reflected in these statements.

\section{CSR Awareness among Factory Owners}

According to the sample data $80 \%$ of the owners agreed that they are aware about the concept of CSR. But the thing is the most common understanding of CSR relates to sponsorships of community activities, contribute to philanthropic activities, helping to poor people, support for children's educations and donations to good causes. Though they have heard about the concept they have very narrow understanding about the CSR.

\section{Recording of CSR}

All the company owners agreed that they are keep records about their CSR activities and $80 \%$ of them agreed that they publish in annual employee welfare meetings and smallholder welfare meetings. They believe that through publishing about company CSR activities it can improve the moral, loyalty, and the society perception about the firm. According to their idea it is proved that the main reason for them to engage in CSR activities to receive future benefits.

\section{Human Resource Policies}

Majority of tea manufacturing (80\%) companies do not have human resource strategy, No any company has assign employee to handle human resource maters, but almost all of them agreed that they have allocate resource for human resource management. $20 \%$ of respondent agreed that they set targets to achieve under their human resource policy. According to above data it is proved that human resource policy implementations in tea manufacturing sector is very poor. 


\section{Employee Income}

All the respondent strongly agreed that they are comply with the minimum wage rate and employees are paid a higher salary than minimum wage rate. Almost $60 \%$ of respondent agreed moderately for the practice of always trying to give a higher salary for employees and other $40 \%$ answered "agree" for this question. Approximately its mean value 3.4 and this confirmed that company commitment to increase employee salary is in moderate level. Almost all the factory owners responded that they are not formally conduct a cost of living survey; all of them answered "Disagree" with this question. But the only 2 factory owners agreed that they get feedback from employees regarding company practices. A Rathnasiri (2003) state that in Sri Lankan private sector is very poorly practice cost of living survey for setting salary rate for its employees. According to his findings only $18 \%$ of firms conduct cost of living surveys. In the sample tea manufacturing companies practices regarding annual increments and bonus are in moderate level and it is confirmed by the mean value of 3.4 for that practice. When it consider about the overall level of tea manufacturing company's practices, it is in a moderate level because the overall mean value of company practices regarding employee's income is about approximately 3.4

\section{Workers Rights}

A core area of CSR is the role and rights of workers (Saji M Kadavil, 2005). According to the broader definitions of CSR workers rights play a vital role. All the factory owners strongly agreed that they are complying with labor laws and they have policies to protect workers' rights. But only $40 \%$ of them had good knowledge about labor law are practiced in Sri Lanka.

\section{Workers Health, Housing and Sanitary}

Healthy work force is very important for an organization because healthy worker can work effectively and gain more contribution to the organization. The Medical Wants (Health) Ordinance of 1912, amended in 1967 and 1974 lays down the rules for medical wants of the estate workers. It also lays down the rules for standard sanitary conditions in the tea estates. Almost only $40 \%$ of respondent agreed that they have separate dispensary with good facilities and other state employees take their medical facilities from provincial hospitals near to the state. 
In the study of institute of social development (2008) states that medical facilities in health sector is not sufficient for the population live in states.

\section{CSR for Small Holders}

According to report of FIAS (2006) tea smallholders and the employees (labors) are very important stakeholders of the tea value chain.Other than only $20 \%$ of respondent all others responded negatively that they haven't policy to respecting the rights and needs of the smallholders. If the companies do not give chance to smallholders to say their ideas and their requirements it can't expect optimistic level of CSR practices from tea manufacturing companies toward smallholders.

\section{Income of Smallholders}

Majority of the smallholders of the sample main source of monthly income is the income they receive by selling raw tea leaves. Majority of owners' $(60 \%)$ answered with the answer of "agree" and others moderately agreed that they use a reasonable price formula to decide the price they offer for smallholders' raw tea leave kilo gram. But only one responder explained clearly the way they decide the price. Almost $60 \%$ of owners moderately agree that smallholders receive a higher price always but they mentioned when the season of high tea crop the price is discriminated by checking the quality.

Majority of owners (60\%) moderately agreed that there are no big price variations and some of them mentioned that in past 5 years price of made tea in international market fluctuated significantly with the international crisis. But they mentioned that now there is stable price in international market and all of the respondents are not satisfy with the international price. Almost $60 \%$ of owners moderately agreed for the question of "You believe that the price is enough for them to cover their production cost", same amount of respondent responded moderately that smallholders can receive advance any time and only one owner agreed that they have a policy to repay their transportation cost by adding to the price of the raw tea leaves. 


\section{Other Supports for Smallholders(Extension Services)}

All the tea manufacturing company owners agreed that they are doing favors to smallholders in different way. Almost $60 \%$ of owners responded that they are not doing training and development workshops and $40 \%$ of them moderately agreed that they are doing workshops with the collaborations of agro business companies and tea board. All the tea factories have a smallholder welfare organization and $40 \%$ of owners responded that they have strong and active welfare organization. The mean value of 4.2 confirmed that the tea manufacturing companies this practice is in a satisfactory level. Almost 60\% responded answered with answers of "strongly agree" and "Agree" that they support to smallholders to purchase fertilizer at low price. They agreed that smallholders can purchase fertilizer from their factories with enjoying the government fertilizer relief and they mentioned that because of this support smallholders can

save higher amount of transportation cost. All of them moderately agreed that they are support to education and health of smallholder families and they agreed that they don't have any establish program for health and education. $60 \%$ of them mentioned that they give scholarships to university students. Majority of respondent (80\%) disagreed for Small holders receive financial subsidies for natural disasters. $40 \%$ of them mentioned that they hope to start such kind of program through smallholder welfare organization. There is a need for such kind of CSR of tea manufacturing companies because most of the smallholders are totally depend on the income they receive by selling raw tea leaves.

\section{CSR for Environment}

A greater commitment to CSR has been one solution to mitigate some of negative social and environmental impacts of companies. "Although the future of CSR faces many challenges ahead, already there is a promising suggestion that CSR is a step towards sustainable development" (Vongsuksiri, 2007:6). "Sustainable development is a political concept for human social, economic and environmental progress" (Brundtland, 2004:3). "The tea plantation sector's environmental footprint is considerable" (Sanne van der Wal, 2008). Tea plantation is more deal with environment therefore tea manufacturing company's practices regarding environment protection and minimum resource consumption and waste very important for the sustainable development of the sector. 


\section{Conservation of Natural Environment}

The tea manufacturing companies' continuous commitment to protect environment is in an acceptable level according to their answers for the structured questionnaire. But when questioned only one owner could explain their environment policy clearly covering all the areas. All the owners' moderately agreed that they are allocating adequate resources to protect and keep cleanly environment. None of the observed tea factory has received ISO 14000 environment certificate.

Majority of owners (60\%) agree that they have company policy towards disposal and reduction of toxic materials. Only two owners said that they return empty chemical bottle to their suppliers. When it consider about the company's overall practices level regarding environment protection is in an acceptable level in the perspective of owners.

\section{Resource Consumption and Minimum Waste Practices}

The commonly used definition of sustainable development emphasizes ethics and environmental protection as the ability of the current generation to meet its needs without compromising the ability of future generations to meet their needs (Brundtland, 2004).To achieve sustainable development it should consider about resource consumption and minimum waste. None of the respondent strongly disagrees for any statement and almost $60 \%$ answered with the answer of "agree" that they have efficient policy on preventing and minimizing waste. They mentioned that in the tea manufacturing process there is some amount of waste and no any harm for environment because it is natural thing. They mentioned that to maintain the quality of made tea they have to bare some waste, Further they said that in the production process very matured tea leaves and less quality tea leaves are removed as waste. Almost $80 \%$ of respondent answered with the answers of "strongly agree" and "agree" that they have efficient practices to preservation of water resources. As a CSR practice all the businesses should give a more attention regarding water resources because the survival of the lives on the earth is depend on the water. Today most of the countries in the world (Human Development report, 2010) suffer from drinking water problems and even in some areas in Sri Lanka suffer from this matter.

All the respondent responded agree that they have efficient disposal methods for spoiled water. Through observation researcher could see that majority of the tea manufacturing companies have 
an acceptable level of disposal methods for spoiled water. Almost $60 \%$ of the owners moderately agreed that they train employees to minimize waste and environment protection.Tea manufacturing companies overall commitment for minimumresource consumption and waste is in moderate level and it is confirmed by the mean value of 3.4.

Up to now it is discussed about the tea manufacturing companies CSR practices regarding employees, smallholders and environment in the perspective of owners. According to their responds some of the practices are in satisfactory level, some of them are not in an acceptable level and should be improved. There is a need for consider the perspectives of employees and smallholders regarding CSR practices of tea manufacturing companies to assess the socio economic impact of CSR practices.

\section{Employee's Perspective about CSR Practices}

The employee perspective on Corporate Social Responsibility was captured by a study questionnaire circulated among a sample of employees from the tea manufacturing companies. Apart from the responses to the questionnaires, responses to unstructured interviews were also analyzed. Almost $60 \%$ of interviewed people are female and $71 \%$ of people are married and some of them are widowed. Majority of employees in tea factories are aged people (35-64) and there were only limited young people, most of them are office workers. Most of the employees (72) of the sample are live in line rooms of the tea estates and others (including office workers) are come from villages and urban areas.

\section{Employee Perspective about Their Income}

A downward pressure on the price paid for tea as well as on daily wages causes poverty and great distress among hundreds of thousands of people whose livelihood depends wholly on the tea sector (Oldenziel, 2006). Lower prices for tea are passed on to a country's less advantaged social groups in the form of lower wages combined with high inflation. (Oldenziel, 2006).According to research findings almost $60 \%$ of employees have answered with "disagree" and strongly disagree" for the statement of company has reasonable wage policy. Their perspective about company's wage policy is not in good position it is confirmed by the 2.17 mean value and according to their response they have not perceived a good economic impact from the company wage policy. Most of the employees said that their salary is not enough for 
living because today price levels of the consumer goods are very high. Almost $49 \%$ of employees are strongly dissatisfied with their compensation package provide by the company. Institute of social development (2008) states, wages paid at present are reasonable and affordable, as far as workers are concerned. It is advisable to always compare the wage against the cost of living index, in the future as well.

\section{Employee's Perspective about Their Rights}

As an employee of any organization they have some right passed by some lows and international organizations. To become good corporate citizen employers should protect the employee's rights as a part of their common CSR agenda. According to the ILO (international labor organization) core labor rights are freedom from forced labor, no child labor, freedom of association and right to collective bargaining, freedom from discrimination (Oldenziel, 2006). Almost 69\% of employees answered with the answers of "disagree" and "strongly disagree" for the statement of management don't violate rules and regulations. It confirmed that most of the employees have not experienced good rules and regulations practices of management and employees are not satisfied with company practices. Almost 49\% employees strongly disagreed and $29 \%$ disagree that no any discrimination pertaining to gender, political opinion, nationality or social origin, they mentioned that they have experienced discrimination in the work place as well as in the society. According to these figures tea manufacturing companies' practices and policies has not been made a positive impact of social development of employees.

\section{Housing, Sanitary and Health Practices in the Perspective of Employees}

As a human been housing, sanitary and health facilities are considered as primary needs for acceptable level of living stand. None of the respondent strongly agrees for any statement regarding housing and sanitary facilities. Almost 53\% of employees moderately agreed that companies conduct effective health clinic program and they have perceived a moderate level impact from companies' health and safety practices. Same as $49 \%$ of employees moderately agreed that they are satisfied with health facilities provided by the factory. When it consider about the overall situation companies health and safety practices have not made a good impact for social and economic development according to employees perspective. It confirmed by the low mean value of 2.23 . 
Researcher of the current research made informal discussion with state dispensary doctors and following discussion is based on their ideas about employee's health condition and observations. This is very important as there are many shortcomings, weaknesses and disabilities among the estate workers. The main weaknesses are low hemoglobin (anaemia) due to lack of proteins and minerals, and not getting proper treatment for worms. As a result workers get weak and lethargic to work and are easily prone to various sicknesses, out-turn will also be less, if it is a female, this will badly affect their fertility, and children. Doctors mentioned malnutrition is also very common especially among children. Poor health conditions and less education among woman are the main reason to have a high still-birth rate and low life span among the workers. In Indonesia, Sri Lanka and Malawi, protective clothing such as masks to protect oneself from inhaling pesticides when applying these chemicals, are often not provided or used (Sanne van der Wal, 2008). Further he mentions that workers in Sri Lanka report severe respiratory as well as skin problems due to such unprotected application.

Almost $57 \%$ of employees strongly disagreed that they have clean and safety living environment and similarly $60 \%$ of respondent strongly disagreed that they have good housing and sanitary facilities. Almost $80 \%$ of employees have no good satisfaction about their housing and sanitary facilities.

I was born in this line houses and now I am 40 years old but still I don't have at least 1 square feet of land. I am citizen in this country and I contribute to generate more income to this country. Salary I earn through this employment is not enough to by a land or build a house, I don't know, who is the responsible party for this problem

Almost all the employees agreed that children of the employee families get the benefit of day care center and majority of employees' appreciate that service of the tea manufacturing company. This service makes a good impact for the social and economic development. Women can continue their job after maternity leaves because they don't want to wary about the security of their kids. According to Saji M Kadavil (2005) providing child care services to employee families it gain benefits to the company not on only for the mothers and kids. 
When it consider about the overall situation tea plantation company's CSR regarding employees income, housing and sanitary, and health are not in satisfactory level, have not been made a good impact and should be improved.

\section{Employee's Perspective about Environment Practices}

Environment practices are considerable factor when the company's CSR activities are analyzed. The company has a key role to play in identifying and implementing remedial actions to cover the negative implications of their operations. Almost $50 \%$ of employees responded that companies do not always concerned about environment, approximately $60 \%$ of the employees are not satisfied with the company environment practices and only $8 \%$ of employees agree with that, most of them are office employees. Only 44\% of employees moderately agree that "No impact from application of pesticides and chemicals to environment and society". Others did not agree. And others mentioned that application of pesticides and chemicals directly badly impact on health condition of employees and the people live in surrounding. Only $20 \%$ of employees agree that company encourage them for environment conservation but majority of employees did not agree. According to the observation researcher also could see tea manufacturing companies have acceptable level disposal method of spoiled water. When consider about overall response it could see employees have not perceived good environment practices of tea manufacturing companies.

\section{Satisfaction of Employees about CSR}

According to the respond of employees only $10 \%$ of emploees responded that they are satisfiy with the company CSR practices but most of them are office employees. Almost $42 \%$ of emplooyees have moderate satisfaction about company CSR practicces. But more than that amount employees (48\%) are dissatisfied and strongly dissatisfied with the company CSR regarding employees. This situation give a signal that tea manufacturing companies CSR towards employees have not made a good impact for social and economic development of employees.Therefore tea manufacturing company management should rethink about their

policies and practices regarding employees. "The socio-economic conditions of the plantation workers and the surrounding Communities are poor" (Sanne van der Wal, 2008).

\section{Smallholder's Perspective about CSR Practices}


According to report of FIAS (2006) tea smallholders are very important stakeholders of the tea value chain. Main purpose of the part is to analyze the perspective of smallholders regarding tea manufacturing company's CSR towards smallholders and the environment.Almost $79 \%$ of the respondents are full time smallholders and they are not doing any other job having a small tea holder. Others agreed that they have a job, they have engaged with cultivation of tea while doing their job. It indecates that smallholders family consumption is fully depend on the price offer by the tea factory of the raw tea leaves, therefore tea manufacturing companies CSR Regarding smallholder's income is very important to analys in the perspective of smallholders.

\section{Smallholder's Perspective about Their Income}

Smallholders are mostly price takers (Sanne van der Wal, 2008). Therefore they have to sell their raw tea leave production to factories for the determined price by the tea factor. Almost $60 \%$ of smallholders responded that company does not pay reasonable price for tea leaves. Only $11 \%$ of had a positive respond and they agreed that company pay reasonable price for raw tea leaves. This kind of respond of smallholders indicates that tea manufacturing companies pricing practices have not been made a good impact on smallholders. Almost $69 \%$ of respondents moderately agreed and $14 \%$ of them strongly disagreed for the statement of "price is enough you to cover production cost". Most of the smallholders mentioned that they have to bear a higher cost for higher labors. $43 \%$ of smallholders disagreed and $40 \%$ of them moderately agreed with the statement of "no big price variations". It indicates that the companies have not taken effective action to minimize price variations under company raw tea leave pricing practices. Only $43 \%$ of them moderately agreed that they are satisfied with overall income from selling tea leaves. When

it considers about overall perspective of smallholders it is in "disagree" level, it is confirmed by the overall mean value of 2.11. This indicates that tea manufacturing companies CSR regarding smallholder's income have not made a positive impact for the social and economic development.

\section{Smallholder's Perspective about Other Services}

"Another important issue is the lack of extension services" (Sanne van der Wal, 2008). Almost $57 \%$ of the respondent Disagreed and strongly disagreed that they are not receiving the support of training and development program to improve their knowledge. Only $43 \%$ of smallholders moderately agreed. "It was observed that as a result of low prices and a lack of proper training 
and awareness on the part the cultivators they fail to maintain their gardens properly" (Sanne van der Wal, 2008). Majority of smallholders answered (57\%) "Agree" for the statement of "you are receiving valued benefit of formed welfare organization". Tea manufacturing company's welfare activities have been made a moderate level of impact and it confirmed by the 3.57 mean value.

Majority of smallholders (58\%) strongly agreed that tea manufacturing company's support to purchase fertilizer at a low cost. They responded that because of company this support they can save some money. Otherwise they have to spend for transportation cost. Only $11 \%$ of smallholders agree that they are satisfied with company overall extension services but majority of them are not satisfy because majority of them (57\%) disagreed for the question as well as 2.5 mean value also indicate that lower level satisfaction among smallholders.

\section{Smallholder's Perspective about Environment Practices}

An important element of management strategy is managing how stakeholders view a company's impact on the natural environment (Chatterji, 2007). None of the responder strongly agrees for any statement regarding company environment practices. Almost 57\% of smallholders responded that there is no positive impact of company environment practices by expressing the answer of "disagree" and $36 \%$ of them strongly disagreed with the statement. This indicates that smallholders have not perceived a positive impact from company environment conservation practices. Almost $86 \%$ of the smallholders are not satisfied with the company environment practices and only $14 \%$ of smallholders moderately agreed that they are satisfied with the company practices. When consider about overall response of smallholders it could see they have not perceived good environment practices of tea manufacturing companies because most of the smallholders answers lie between moderate, disagree and strongly disagree.

According to the respond of smallholders only $12 \%$ of them responded that company overall CSR practices are "good". But no any smallholders has felt that company CSR practices are "very good". Almost 54\% of smallholders expressed that Tea manufacturing company's CSR are moderatly good. $17 \%$ of smallholders have felt that company CSR practices are poor and others mentioned that company CSR practices are very poor. This situation give a signal that tea manufacturing companies CSR towards smallholders have not made a good impact for social and 
economic development of smallholders. Because majority of the smallholders have not felt that CSR of company is good are very good.

\section{Hypotheses Testing}

Table 01: Pearson's correlations for hypothesis testing

\begin{tabular}{|l|l|l|l|}
\hline & $\begin{array}{l}\text { The level of impact } \\
\text { on socio economic } \\
\text { condition of } \\
\text { employees }(\mathrm{H} 1)\end{array}$ & $\begin{array}{l}\text { The level of } \\
\text { impact on socio } \\
\text { economic } \\
\text { condition of } \\
\text { smallholders }(\mathrm{H} 2)\end{array}$ & $\begin{array}{l}\text { The level of } \\
\text { impact on overall } \\
\text { socio economic } \\
\text { condition } \\
(\mathrm{H} 3)\end{array}$ \\
\hline Pearson Correlation & $.885\left(^{*}\right)$ & $.924\left(^{*}\right)$ & $.896\left(^{*}\right)$ \\
\hline Sig. (2-tailed) & .046 & .025 & .040 \\
\hline $\mathrm{N}$ & 70 & 70 & 145 \\
\hline
\end{tabular}

Correlation is significant at the 0.05 level (2-tailed).

Source: Primary

H1: Company CSR level for employees will impact on socioeconomic condition of employees.

According to the results of Pearson's correlation analysis for H1 were presented in Table 6.1 below correlation is significant at the 0.05 level (2-tailed). Therefore there is a positive relationship between Company CSR level for employees and the socioeconomic condition of employees. This means when company increase CSR level for employees, it leads to improve the socioeconomic condition of employees. It can conclude that Company CSR level for employees will impact on socioeconomic condition of employees, $\mathrm{H} 1$ is supportive.

H2: Company CSR level for smallholders will impact on socioeconomic condition of smallholders

According to the presented results (see table6.1) of Pearson's correlation analysis for H2, correlation is significant at the 0.05 level (2-tailed). Therefore there is a positive relationship between company CSR level for smallholders and the socioeconomic condition of smallholders. 
This means when company increase CSR level for smallholders, it leads to improve the socioeconomic condition of smallholders. It can conclude that company CSR level for smallholders will impact on socioeconomic condition of smallholders, $\mathrm{H} 2$ is supportive.

H3: Company overall CSR level will impact overall socioeconomic condition.

According to the results of Pearson's correlation analysis for H3 were presented in Table 6.1 below, correlation is significant at the 0.05 level (2-tailed). Therefore there is a positive relationship between company overall CSR level and the socioeconomic condition. This means when company improves the CSR practices for employees, smallholders and the environment; it leads to enhance the socioeconomic condition. It can conclude that company overall CSR level will impact overall socioeconomic condition, $\mathrm{H} 3$ is supportive.

\section{Conclusion}

This study attempted to investigate the CSR status of Sri Lankan tea manufacturing companies and its impact on socioeconomic condition of employees and tea smallholders. According to the tested hypotheses all the three hypotheses are supportive and it indicates that there is a positive relationship between tea manufacturing company CSR level and the socioeconomic condition of the employees and tea smallholders.

\section{CSR for Employees}

Tea manufacturing company CSR practices towered employees will make a positive impact on socioeconomic condition of employees. The impacts of CSR on the employees are significant because it leads to their productivity; improve their moral and positive perception about the company. In the current research study it assessed the tea manufacturing companies CSR practices regarding its employees under three domain; Employee income, workers rights, and health, housing and sanitary. When it consider about the overall level of tea manufacturing company's practices regarding employee's income, it is in a moderate level. However, from the perspective of employee's policies and practices regarding employee's income have not been positively impact on employee's social and economic development.

When it considers about overall level of policies and practices regarding workers right, it is in a satisfactory level. But it should consider about employee perspective to assess the real impact of 
company policies and practices regarding this matter. Most of the employees have not perceived a positive impact of practices regarding transparent decision making and communication. Employees have not perceived good level of practices and according to their respond companies practices are poor. Therefore there is a need for revised and improve the practices regarding workers rights of tea manufacturing companies.

Healthy work force is very important for an organization because healthy worker can work effectively and gain more contribution to the organization. Most of the companies do not have separate dispensary with good facilities. Overall practices of tea manufacturing companies' regarding health and housing practices towards employees are in moderate level. Overall impact of company's practices regarding employees housing, sanitary and health are poor in the perspective of employees. Therefore companies should enhance the practices and improve the quality of the practices and policies regarding this matter.

\section{CSR for Smallholders}

Tea manufacturing company CSR practices towered smallholders will make a positive impact on socioeconomic condition of smallholders. The impacts of CSR on the smallholders are significant because it leads to improve their moral, loyalty and positive perception about the company. In the current research study it assessed the tea manufacturing companies CSR practices regarding its smallholders under two domain; smallholders income, Other support (extended services).

Most of the companies haven't got a policy to respecting the rights and needs of the smallholders. Majority of the smallholders depend on the monthly income they receive by selling raw tea leaves. Tea manufacturing companies overall practices level regarding smallholder's income is in a moderate level. Tea manufacturing companies CSR regarding smallholder's income have not made a positive impact for the social and economic development of smallholders. Therefore tea manufacturing companies should improve the practices and policies regarding smallholder's income.

All the tea manufacturing company owners agreed that they are doing favors to smallholders in different way. Most of the smallholders have not perceived a positive impact of companies training and development program to improve their knowledge. Tea manufacturing company's 
welfare activities have been made a moderate level of impact on smallholders. Most of the smallholders are not satisfied with company overall extension services but majority of them are not satisfy. Therefore tea manufacturing companies should restructure and improve the extension services regarding smallholders.

\section{CSR for Environment}

All the factory owners agreed that they have policy to environment protection. But when questioned only one owner could explain their environment policy clearly covering all the areas. None of the observed tea factory has received ISO 14000 environment certificate. When consider about overall response it could see employees have not perceived good environment practices of tea manufacturing companies in the perspective of employees.

Resource allocation for environmental protection and upgrading is not at a satisfactory level. Companies are in the initial stage of understanding the CSR agenda related to environmental protection and resource allocation.

The implementation of CSR practices can help the companies to achieve their organizational goals. The strong commitment of the company to CSR raises the public's perception of CSR activities. It is important for these activities to be addressed socio-economic issues and distributed the benefits equally to the community. Otherwise, there may be a negative impact on the company's reputation and image.

\section{Recommendations to the Tea Manufacturing Companies}

Tea plantation company management should improve their awareness about sustainable development, business ethics, human rights,labor rights and labor laws, human resource management, and corporate governance practices and adopt with good level of practices regarding these matters. Tea manufacturing companies should improve the policies and practices regarding employee's income to make a positive impact on socioeconomic condition of employees. Companies are recommended to start projects with the collaboration with the government and NGO's to improve housing, sanitary, water and other infrastructure.Tea companies should establish practices and policies to respect smallholder's rights and needs. Further they are recommended to conduct smallholder opinion surveys to get the perception and 
ideas of smallholders regarding company practices.Tea manufacturing companies should use very specific and acceptable price formula to decide the price of raw tea leaves and they should improve the transparency of their pricing method to smallholders. The companies should strictly comply with environmental laws, rules and regulations in order to minimize environmental disturbances. The company has ethical responsibility to contribute the sustainable environment development by maintaining the ecological balance.

\section{References}

Aaron K. Chatterji, D. I. (2007). How Well do Social Ratings Actually Measure Corporate Social Responsibility? Working Paper Series, Center for Responsible Business, UC Berkeley.

Abagail Mc Williams, D. S. (2005). Corporate Social Responsibility: Strategic Implications. New Yourk, USA: Department of Economics, Rensselaer Polytechnic Institute.

Amaeshi K. M., A. B. ( 2006). 'Corporate Social Responsibility in Nigeria: Western Mimicry or Indigenous Influences? Journal of Corporate Citizenship, , 24, winter: 83-99.

Ariyabandu M M, H. p. (2002). Corporate Social Responsibility and Natural Disaster Reduction in Sri Lanka. Colombo, Sri Lanka: ITDS-South Asia.

Baker.M. (2009). Retrieved 08 12, 2011, from http://www.mallenbaker.net/csr/definition.php

Barbara Beliveau, M. C. (1994). Predicting Corporate Social Responsiveness: A Model Drawn from Three Perspectives. Journal of Business Ethics, Springer, Vol. 13, No. 9, pp. 731738.

Baucus M S, B. D. (1997). Paying the piper: a empirical examination of longer-term financial

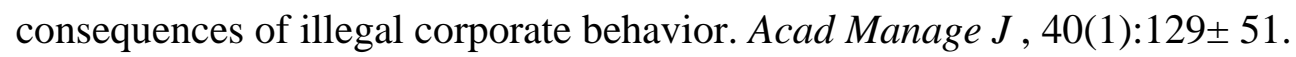

Bert Scholtens. (2006). Finance as a Driver of Corporate Social Responsibility. Journal of Business Ethics, Springer, Vol. 68, No. 1, pp. 19-33.

Branco.M C, R. L. (2007). Positoning Stakeholders Theory Within the Debets on Corporate Social Responsibility. Electronic Journal of Business Ethics and Organization Studies . 
Brenda E. Joyner and Dinah Payne. (2002). Evolution and Implementation: A Study of Values, Business Ethics and Corporate Social Responsibility. Journal of Business Ethics, Vol. 41, No. 4 , pp. 297-311.

Brundtland, G. (2004). 4th Annual Peter M. Wege Lecture on Sustainability,. Lydia.

Bryman.A. (2008). Social Research Methods 3rd Edition. New York: Oxford University Press.

Carmen Valor. (2005). Corporate Social Responsibility and Corporate Citizenship: Towards Corporate Accountability. Business and Society Review , 191-212.

Carroll, A. B. (1999). Corporate Social Responsibility: Evolution of a Definitional Construct. Business \& Society, 268-295.

Central Bank of Sri Lanka. (2010). ANNUAL REPORT. Central Bank of Sri Lanka, 30, Janadhipathi Mawatha, Colombo, 00100.: Printed at Printcare Packaging (Pvt) Limited,ISBN 978-955-575-213-8.

Corporate Sustainability Conference 2002: The Impact of CSR on Management Disciplines. (2003). Journal of Business Ethics , pp. 89-93.

Dahlsrud, A. (2006). How Corporate Social Responsibility is Defined: an Analysis of 37 Definitions. Trondheim, Norway: Wiley InterScience.

Davidson, W. N. (1990). A comparison and test of the use of accounting and stock market data in relating corporate social responsibility and financial performance. Akron Bus Econ Rev, $21: 7 \pm 19$.

Deegan, C. (2004). Financial Accounting Theory,. McGraw-Hill Australia Pty Ltd, NSW.

Department of Census \& Statistics. (2005). Census of tea Small holdings. Colombo, Sri Lanka: Department of Census \& Statistics.

Department of Census \& Statistics. (2004). District and Provincial Level Tables of the Sri Lanka Labour Force Survey. colombo, Sri Lanka: Department of Census \& Statistics. 
Dima Jamali and Ramez Mirshak. (2007). Corporate Social Responsibility (CSR): Theory and Practice in a Developing Country Context. Journal of Business Ethics, Springer, Vol. 72, No. 3 , pp. 243-262.

Doane, D. (2004). Beyond corporate social responsibility: minnows, mammoths and markets. Futures 37 (2005) 215-229.

Donna J. Wood. (1991). Corporate Social Performance Revisited. The Academy of Management Review, Vol. 16, No. 4, pp. 691-718.

Edelman. (2004). Edelman Asia Pacific stakeholder study: The only way to have a friend is to be one. Retrieved 08 23, 2011, from htpp://www.edelman.com

Eduardo Sánchez. Corporate Social Responsibility Management Socio-economic impact of companies. UNIVERSITY OF MONDRAGÓN (ETEO) Research Team, Strategy, Organisation Entrepreneurship Department.

Elisabet Garriga and Domènec Melé. (2004). Corporate Social Responsibility Theories: Mapping the Territory. Journal of Business Ethics, pp. 51-71.

Encyclopaedia of the Nations,(2010). Sri Lanka- Overview of economy. (n.d.). Retrieved 08 23, 2011, from http://www.nationsencyclopedia.com/economies/Asia-and-the-Pacific/SriLanka-OVERVIEW-OF-ECONOMY.htm

Foreign Investment Advisory Service World Bank/International Finance Corporation. (2006). A Corporate Social Responsibility (CSR) Diagnosis Module for Application in Value Chain Analysis (VCA).

Frederick, W. C. (1960). The growing concern over business responsibility. California Management Review, , 54-61.

Gareth R. jones, M. M. (2009). ORGANIZATIONAL THEORY, DESIGN, AND CHANGE, 5th edition, Indian reprint. Delhi: Dorling Kindersley (India) Pvt. Ltd.

Gérard Fonteneau. (2003). Corporate Social Responsibility: Envisioning its Social Implications. 
Guido Palazzo and Ulf Richter. (2005). CSR Business as Usual? The Case of the Tobacco Industry. Journal of Business Ethics, Springer, Vol. 61, No. 4, pp. 387-401.

HUGH ALEXANDER GROSSMAN. (2005). REFINING THE ROLE OF THE CORPORATION: THE IMPACT OF CORPORATE SOCIAL RESPONSIBILITY ON SHAREHOLDER PRIMACY THEORY. 573-596.

Illert.M. (2004). Globalisation: Blessing or Curse? Opportunities and Risks of an Unstoppable Development. Forum at Hauptkirche St. Jacobi, Hamburg.

international-Alert, Peace Through Profit: Sri Lankan Perspectives on Corporate Social Responsibility. (2005).

ISD Kandy in collaboration with PiC, New Delhi,. (2008). SustainabiliTea, REport on Sri Lankan Tea Industry. Kandy: Institute Of Social Development.

Jan Lepoutre and Aimé HeeneSource. (2006). Investigating the Impact of Firm Size on Small Business Social Responsibility: A Critical Review. Journal of Business Ethics,Springer, Vol. 67, No. 3, pp. 257-273.

Joris Oldenziel \& Myriam Vander Stichele. Trade and the need to apply international Corporate Social Responsibility (CSR) standards. Keizersgracht, The Netherlands: Centre for Research on Multinational Corporations, (SOMO).

Joris Oldenziel. (2006). Sustainabilitea, The Dutch Tea Market and Corporate Social Responsibility. SOMO - Centre for research on Multinational Corporations.

Kashyap. R, M. R. (n.d.). Corporate Social Responsibility: a Call For Multidisciplinary Inquiry. Journal of Business and Economic research, Volume 2 (7):51-58.

Klugman, J. (2010). Human Development Report, 20th Anniversary Edition, The Real Wealth of Nations, Pathways to Human Development. 1 UN Plaza, New York, NY 10017, USA: The United Nations Development Programme Human Development Report Office, ISBN: 978023028445690101. 
Krishnamurthy Sriramesh, C. W. (2007). Corporate Social Responsibility and Public Relations: Perceptions and Practices in Singapore. International Public Relations Symposium, Bled, Slovenia.

Kumudini Heenetigala. (2011). Corporate Governance Practices and Firm Performance of Listed Companies in Sri Lanka.

Lance Moir. (2001). WHAT DO WE MEAN BY CORPORATE SOCIAL RESPONSIBILITY? Bedford, England.

Levy. F. (2006). Moving From Gut to Metrics, Leading Perspectives, A Trends and Solutions Publication From Business For Social Responsibility,. San Francisco, USA.

Maimunah ISMAIL. (2009). CORPORATE SOCIAL RESPONSIBILITY AND ITS ROLE IN COMMUNITY DEVELOPMENT: AN INTERNATIONAL PERSPECTIVE. The Journal of International Social Research, Volume 2 / 9; 200-2009.

Marjo Elisa Siltaoja. (2006). Value Priorities as Combining Core Factors between CSR and Reputation:. Journal of Business Ethics, Springer, Vol. 68, No. 1 , pp. 91-111.

Mark S. Schwartz and Archie B.Carroll. (2003). A Three-Domain Approach. Business Ethics Quarterly, Vol. 13, No. 4, pp. 503-530.

Mark, J. (1994 (July) ). Socially responsible organizational buying: environmental concern as a noneconomic buying criterion. Drumwright ME. , 58.

Menon, A. ,. (1997). Environmental marketing strategy: the emergence of corporate environmentalism as market strategy. J Mark (January) , 61:51.

Mick Blowfield. (2003). Ethical Supply Chains in the Cocoa, Coffee and Tea Industries. Greenleaf Publishing, Center for Corporate Citizenship, USA, 15-24.

Ministry of Estate Housing, Infra-structure \& Community Development. Three Year Development Plan, 2006 - 2009, . Colombo, Sri Lanka.

Miyan. M A. (2006). Dynamics of Corporate Social Responsibility-Bangladesh Context, Dhaka, Bangladesh. Retrieved 08 02, 2011, from http://www.researchsea.com/htmldownload 
Monaghan, P. B. (2003). Business and Economic Development, The Impact of Corporate Social responsibility Standards and Practices,. Branford, U.S.A.

Mummullage Sanjeewani Nanayakkara. (2010). Socio-economic impacts of Corporate Social Responsibility practices in Sri Lankan domestic manufacturing companies (With Reference to Harischandra Mills PLC, Matara, Sri Lanka).

Obalola, M. (2008). Beyond philanthropy: Corporate Social Responsibility in the Nigerian insurance industry,. Social Responsibility Journal, Emerald Group Publishing Limited. , Volume 4(4).

Overland, J. (2007). Macquarie Law Working Paper Series, Macquarie Law WP 2007-7, ISSN 1835-2286. Corporate Social Responsibility in Context: The Case For Compulsory Sustainability Disclosure For Listed Public Companies in Australia? , .

Rathnasiri, H. C. (2003). Corporate Social Responsibility Practices of Sri Lankan Private Sector: An Exploratory Study. Sri Lankan Journal of Management, Vol. 8, Nos. 3 \& 4, pp 195228.

Reinhard Steurer, M. E. (2005). Corporations, Stakeholders and Sustainable Development I: A Theoretical Exploration of Business-Society Relations. Journal of Business Ethics, Springer, , Vol. 61, No. 3, pp. 263-281.

Reinhard Steurer, M. E. (2005). Corporations, Stakeholders and Sustainable Development I: A Theoretical Exploration of Business-Society Relations. Journal of Business Ethics, Springer, , Vol. 61, No. 3 , pp. 263-281Published.

Saji M Kadavil. (2005). Indian Tea Research. Kolkata: Tea Board of India.

Sandra L. Gill. (2007). Corporate Social Responsibility: Issues and Implementation in APO Member Countries. Kuala Lumpur, Malaysia: Asian Productivity Organization,Project Number 07-RP-13-GE-STM-A: Study Meeting on Social Dimensions of Productivity.

Sanjay Pradhan, A. R. (2010). Corporate Social Responsibility in Rural Development Sector: Evidences From India. School of Doctoral Studies (European Union) Journal , 139-147. 
Sanne van der Wal. (2008). Sustainability Issues in the Tea Sector,A Comparative Analysis of Six Leading Producing Countries. 1018 GL Amsterdam, Netherland: Stichting Onderzoek Multinationale Ondernemingen (SOMO), Centre for Research on Multinational Corporations.

Satya Menon, B. E. (2001). CORPORATE SPONSORSHIPS OF PHILANTHROPIC ACTIVITIES: WHEN DO THEY IMPACT PERCEPTION OF SPONSOR BRAND?

Schmidheiny, S. ( 2006). 'A View of Corporate Citizenship in Latin America'. Journal ofCorporate Citizenship, 21, spring, 21-4.

Shaker A. Zahra and Michael S. LaTour. (1987). Corporate Social Responsibility and Organizational Effectiveness: A Multivariate Approach. Journal of Business Ethics, Springer, Vol. 6, No. 6, pp. 459-467.

SOCIAL AND ECONOMIC IMPACT: MEASUREMENT, EVALUATION AND REPORTING; SELECTED FINDINGS. (2010). Ethical Corporation, www.ethicalcorp.com/reports.

Spicer, B. H. (1978). Investors, Corporate Social Performance and Information Disclosure: An Empirical Study. The Accounting Review , pp. 94-111Published.

Stichting Onderzoek Multinationale Ondernemingen (SOMO),. (2009). CSR Intervention Training Workshop for Tea and Garment Sector NGOs and TUs: WORKSHOP REPORT. Kandy: Institute Of Social Development.

Suparn Sharma, J. S. (2009). CORPORATE SOCIAL RESPONSIBILITY: THE KEY ROLE OF HUMAN RESOURCE MANAGEMENT. Business Intelligence Journal , 205-213.

Tea board. (2006). Statistical Bulletin. Thalawakale, Sri Lanka: Sri Lanka Tea Board.

Terrence Guay, J. P. (2004). Non-Governmental Organizations, Shareholder Activism, and Socially Responsible Investments: Ethical, Strategic, and Governance Implications. Journal of Business Ethics, Springer, pp. 125-139.

The Tea Small Holdings Development Authority (TSHDA). (2006). Tea smallholder census . Colombo, Sri Lanka. 
Tom Fox, H. W. (2002). PUBLIC SECTOR ROLES IN STRENGTHENING CORPORATE SOCIAL RESPONSIBILITY: A BASELINE STUDY. International Institute for Environment and Development (IIED), The World Bank.

Übius, U. (2009). The impact of Corporate social responsibility, and organizational and individual factors on the innovation climate. Tallinn: EBS print.

Uditha Liyanage. From CSR to SRB. Collombo, Sri Lanka.: The Institute of Char tered Accountants of S ri L ank a.

United Nations Department of Economic and Social Affairs. (2007). Sustainable Development Innovation Briefs, CSR and developing countries, What scop of government action? New York, USA: United Nations Department of Economic and Social Affairs,Division for Sustainable Development, Policy Integration and Analysis Branch.

Vershoor, C. C. (1997). Principles build profits; link between corporate social performance and financial and nonfinancial performance. Manage Account , 160.

Vongsuksiri, R. (2007). Global Market Pressures and Corporate Social Responsibility (CSR): Impacts and Implications on Thai Businesses, International Institute for Trade and Development (Public Organization), Thailand. Retrieved 07 13, 2011, from htpp://www.itd.or.th/en/node/868

wayne visser. (2010). CORPORATE SOCIAL RESPONSIBILITY IN DEVELOPING COUNTRIES, c h a p t e r 21 .

Wayne Visser. (2005). REVISITING CARROLL'S CSR PYRAMID AN AFRICAN PERSPECTIVE. KPMG South Africa.

Wayne Visser. (2010). The Evolution and Revolution of Corporate Social Responsibility. In In: Responsible Business: How to Manage a CSR Strategy Successfully (p. CHAPTER 21).

Wickremasinghe, N. C. (2008). A Study of Tea Plantation Operational Aspects in Relation to Operational Workforce. 